\section{Gypsum Effects on Growth and Macroelement Uptake of Field-grown Asimina triloba (Pawpaw) Irrigated with Low-saline, Sodic Water}

\author{
G.A. Picchioni ${ }^{1}$ \\ Department of Agronomy and Horticulture, New Mexico State University, Las \\ Cruces, NM 88003
}

C.J. Graham

Louisiana State University Agricultural Center, Calhoun Research Station, Box 539, Calhoun, LA 71225

\section{A.L. Ulery \\ Department of Agronomy and Horticulture, New Mexico State University, Las Cruces, NM 88003}

Additional index words. provenance, calcium, roots, establishment, survival, sodium adsorption ratio, new crops, water quality

\begin{abstract}
Asimina triloba (L.) Dunal is an underused tree species with demonstrated potential as a new fruit crop and landscape ornamental plant. Best management practices for A. triloba are not adequately defined, particularly for field establishment in high-Na conditions characteristic of numerous southern U.S. production areas. We evaluated the growth and net macroelement uptake of field-grown $A$. triloba seedlings on soil amended with a single addition of gypsum at $0,7.5$, or $15.0 \mathrm{t} \cdot \mathrm{ha}^{-1}$ and later receiving a regular supply of Na-affected but nonsaline irrigation water [sodium adsorption ratio (SAR) of 15.5 and electrical conductivity (EC) at $0.4 \mathrm{dS} \cdot \mathrm{m}^{-1}$. Over two growing seasons, the soil saturation extract Ca concentration increased while the soil saturation extract SAR decreased with increasing gypsum rate. Amending the soil with gypsum increased total lateral branch extension per tree by $60 \%$ to $73 \%$ and trunk cross-sectional area (TCSA) per tree by $68 \%$ to $87 \%$ above a non-gypsum-amended control treatment. Total dry matter accumulation and the net uptake of $\mathrm{N}, \mathrm{P}$, and $\mathrm{K}$ per tree were over $100 \%$ greater following gypsum application as compared to controls. The growth and mineral uptake-enhancing effects of gypsum were likely related to functions of $\mathrm{Ca}$ at the root level and on soil physical properties that should be considered in establishing young $A$. triloba trees with irrigation water containing high sodicity but relatively low total salinity.
\end{abstract}

Asimina triloba (pawpaw) has received considerable attention as a new commercial tree fruit crop, landscape ornamental, and medicinal plant (Callaway, 1992; Huang et al., 2003; Layne, 1996; Zhao et al., 1993). However, difficulty in transplanting A. triloba is a barrier toward successful commercialization of the species (Callaway, 1990; Callaway and Callaway, 1992; Darrow, 1975). Several shortterm pot culture fertilization studies have been conducted on A. triloba (Pomper et al., 2002a, $2000 \mathrm{~b}$, and 2000c), but there are no quantitative

Received for publication 4 Aug 2003. Accepted for publication 25 Nov. 2003. This study was supported by the New Mexico Agricultural Experiment Station and Louisiana State Univ. (LSU) Agricultural Center. We thank Charles Johnson (LSU Agricultural Center) for providing Asimina triloba seedlings used in the study, and Peter Gallagher (Louisiana Tech Univ. Dept. of Agricultural Sciences) for providing use of the study site. We also thank Bobby McCaslin and Denise Saucedo-Rodriguez (New Mexico State Univ. Dept. of Agronomy and Horticulture) for helpful comments during preparation of the manuscript.

${ }^{1}$ To whom reprint requests should be addressed; e-mail gpicchio@nmsu.edu. data on factors affecting its growth and mineral uptake characteristics in field conditions. This lack of data is significant, since young $A$. triloba trees are reported to be inherently slow-growing with slowly developing root systems (Darrow, 1975). Enhancement of root growth would speed nursery or orchard establishment, grafting and budding of fruit-bearing cultivars, and regeneration of renewal biomass for extraction of natural products.

High-Na (sodicity) is a transcontinental concern in the southern latitudes of the United States, where it threatens a diversity of existing commercialized tree fruit crops, such as pecan, pistachio, blueberry, citrus, plum, and peach (Karakas et al., 2000; Picchioni et al., 1990, 2000; Wright et al., 1992; Zekri and Parsons, 1990; Ziska et al., 1991). Northern Louisiana is on the southwestern fringe of the A. triloba indigenous zone, where groundwater sodium adsorption ratio (SAR) may exceed 40 and EC, 9 dS $\cdot \mathrm{m}^{-1}$ (U.S. Geological Survey, 1991). Numerous groundwater monitoring stations in northern Louisiana report high salinity combined with ionic imbalances, most notably cases in which Nadominates the cationic fraction, while $\mathrm{Mg}$ and
Ca concentrations are at trace levels to below 1 meq.L $L^{-1}$ (U.S. Geological Survey, 1991). Local groundwater supply during the present study in Ruston (described below) had an average SAR of 15.5 but relatively low average total salinity, expressed as EC, at $0.4 \mathrm{dS} \cdot \mathrm{m}^{-1}$.

Reducing potential sources of environmental stress is essential for successful commercialization of new crops (Wallis et al., 1989). In reference to the present study, the inherent difficulty in field establishment of A. triloba could be exacerbated with $\mathrm{Na}$-affected irrigation waters and soils. Injurious effects of the Na-dominated irrigation waters of northern Louisiana were highlighted in a recent study involving young trees of $\mathrm{Cra}$ taegus opaca Hook. and Arn. (Picchioni and Graham, 2001). Like A. triloba, C. opaca is indigenous to the North American temperate zone and under consideration as a new fruit crop and ornamental tree.

Calcium serves an important role in counteracting negative effects of $\mathrm{Na}$ on irrigation waters, soils, and plants. In addition to its functions at the root level (Epstein, 1961; Hanson, 1984; Picchioni et al., 1991), Ca maintains stable, flocculated clay mineral aggregates that are essential for good soil structure and internal drainage (Bohn et al., 1985). Gypsum is the most widely used neutral Ca salt for maintaining or amending soil structure in Na-affected soils (Mengel and Kirkby, 1987). We hypothesized that gypsum would improve field establishment of $A$. triloba irrigated with sodic, nonsaline water. Therefore, our objective was to evaluate gypsum effects on A. triloba field establishment and the net uptake of macroelements under irrigated conditions of high sodicity and relatively low total salinity.

\section{Materials and Methods}

Preparation of seedling tree material. Seeds of A. triloba were collected in Fall 1993 from fruit of trees growing in the wild along the Mississippi River floodplain and just east of the town of Transylvania in northeastern Louisiana. Seeds were separated from the fruit, rinsed with water, and subjected to coldmoist stratification as prescribed by Layne (1996). After stratification, seeds were sown individually at a depth of $2 \mathrm{~cm}$ in $17-\mathrm{L}$ plastic pots $(27 \mathrm{~cm}$ wide $\times 30 \mathrm{~cm}$ tall $)$ filled with pine bark. Seedlings were grown outdoors at the Calhoun Research Center under 50\% shade and irrigated with tap water (EC of 0.4 to 0.5 $\mathrm{dS} \cdot \mathrm{m}^{-1}$ ) as needed for 16 months until Spring 1995 field planting (described below). Using a photometer (General Electric Model 214), the summer maximum photosynthetic photon flux (PFD) under the shaded conditions was estimated to be 750 to $780 \mu \mathrm{mol} \cdot \mathrm{m}^{-2} \cdot \mathrm{s}^{-1}$. Photometric units were converted to quantum units by the method described by Thimijan and Heins (1983). There were $179 \mathrm{~cm}$ of rainfall over the 16 months of shaded pot culture and the air temperature ranged from -9 to $36{ }^{\circ} \mathrm{C}$ (lowest winter minimum and highest summer maximum temperatures, respectively), according to an on-site weather station.

Fifty-four dormant, unbranched, 16-month- 
old seedlings from pot culture were selected for field evaluation. The seedlings had an average terminal bud height (from top of the medium) of $22.2 \pm 4.1 \mathrm{~cm}$ and trunk diameter $(1 \mathrm{~cm}$ from the ground line) of $4.99 \pm 0.82 \mathrm{~mm}$. At this time, the total dry weight per seedling was $4.62 \pm 0.89 \mathrm{~g}$ determined on six seedlings not used in the field study, after the pine bark medium was washed from the roots with tap water, followed by deionized water, and the seedling biomass dried at $60{ }^{\circ} \mathrm{C}$ for 2 weeks. The total dry weight per potted seedling was similar to that reported in the recent short-term A. triloba pot studies (Pomper et al., 2002a, 2000b, 2000c).

Field site description and cultivation. A 0.05-ha field plot at the Louisiana Tech Univ. horticultural farm in Ruston $(\approx 17 \mathrm{~km}$ west of the Calhoun Research Center) was used for the study. The site was fallow before use in the present investigation. The soil was a Ruston fine loamy, siliceous, semiactive, thermic, Typic, Paleudult, with a brown fine sandy loam in the surface and subsurface layers (to $\approx 15 \mathrm{~cm}$ ), underlain by red clay loam in the upper subsoil. The middle and lower subsoil were comprised of yellowish fine sandy loam and red sandy clay loam, respectively. During the field study growing seasons of 1995 and 1996, the air temperature ranged from -13 to $41^{\circ} \mathrm{C}$ (lowest winter minimum and highest summer maximum temperatures, respectively). The summer maximum PFD (estimated as described above) was 1450 to $1500 \mu \mathrm{mol} \cdot \mathrm{m}^{-2} \cdot \mathrm{s}^{-1}$.

Before planting, raised beds measuring $0.38 \mathrm{~m}$ in height and $0.9 \mathrm{~m}$ in top width were prepared from the top $15 \mathrm{~cm}$ of fine sandy loam scraped from the 4.6-m middle aisles between the marked bed locations. Soil organic matter was determined by the methods described by Nelson and Sommers (1996), averaged 1.0\% in this portion of the profile, and did not change throughout the study. Beds were initially shaped and packed by making three passes with a $23-\mathrm{cm}$-diameter roller, then gypsum $\left(\mathrm{CaSO}_{4} \cdot 2 \mathrm{H}_{2} \mathrm{O}\right.$, pelletized agricultural grade) was tilled into the bed tops to a depth of $15 \mathrm{~cm}$ to provide $\mathrm{CaSO}_{4}$ at 0.0 (control), 7.5, or 15.0 $\mathrm{t} \cdot \mathrm{ha}^{-1}$. The single application of gypsum was made on 3 Apr. 1995, and the rates selected from within the range recommended for agricultural crops (California Fertilizer Association, 1995; Mengel and Kirkby, 1987). Following gypsum application, beds were again packed with the roller. The three application rates were arranged in a randomized complete-block design with three trees per replication and six replications, totaling 18 trees per treatment. The trees were then transplanted on 7 Apr. 1995 atop the beds at a spacing of $5.5 \mathrm{~m}$ between bed centers and 1.5 $m$ within the bed row (1212 trees per ha), and watered thoroughly. Each three-tree replication measured $4.5 \mathrm{~m}$ long $\times 0.9 \mathrm{~m}$ wide. Trees were grown up to their excavation on 17 Oct. 1996 and had experienced two growing seasons in the field in addition to a single growing season (16 months) of pot culture.

Throughout the duration of the study, irrigation was supplied through a manually-operated drip irrigation system with two emitters per tree, each with a flow rate of $4.5 \mathrm{~L} \cdot \mathrm{h}^{-1}$. Emitters were positioned on top of the bed center and at a lateral distance of $30 \mathrm{~cm}$ from the trunks. Each irrigation supplied $\approx 53 \mathrm{~L}$ water per tree, which was estimated to be sufficient to fill the entire pore volume of the fine sandy loam bed. The irrigation source (tap water) had an EC of $0.4 \mathrm{dS} \cdot \mathrm{m}^{-1}, \mathrm{SAR}$ of $15.5, \mathrm{pH}$ of 7.7 , and ion concentrations (in meq. $\mathrm{L}^{-1}$ ) as follows: $\mathrm{Na}$ (4.7), $\mathrm{Ca}$ (0.14), $\mathrm{Mg}$ (0.04), $\mathrm{Cl}$ (1.0), $\mathrm{HCO}_{3}+$ $\mathrm{CO}_{3}(3.0)$, and $\mathrm{SO}_{4}(0.2)$.

No field irrigation guidelines have been established for A. triloba. Therefore, irrigation planning was aided by general orchard irrigation methods as prescribed for similar growing conditions of east Texas by Worthington et al. (1986), while considering local monthly grand average U.S. Weather Bureau pan evaporation data over a prior 20-year period. Local monthly average pan evaporation values for the 1995 and 1996 growing seasons were within $10 \%$ of their previous 20 -year averages. The combined natural precipitation and irrigation met or exceeded allowable soil water depletion as defined by Worthington et al. (1986). During the growing season months of April through October, 16 irrigations $(61 \mathrm{~cm})$ were applied in 1995, nine irrigations ( $34 \mathrm{~cm}$ ) in 1996, with irrigation intervals averaging $12.6 \mathrm{~d}$ for 1995 , and $22.4 \mathrm{~d}$ for 1996 . The lower number, total depth, and frequency of irrigations required in 1996 were the result of $81 \%$ more rainfall during the months of May through October of 1996 as compared to the same months of 1995 (76 vs. $42 \mathrm{~cm}$, respectively).

On three dates during the study (5 May and 24 June 1995, and 28 Apr. 1996), Peters $20 \mathrm{~N}-4.4 \mathrm{P}-16.6 \mathrm{~K}$ water-soluble fertilizer (J.R. Peters, Allentown, Pa.) was added to the irrigation solution using a fertilizer injector (Gewa model 6, Hermann A. Wirth, Princeton, Fla.). Each fertigation solution contained (in $\mathrm{mg} \cdot \mathrm{L}^{-1}$ ) $146 \mathrm{~N}-32 \mathrm{P}-121 \mathrm{~K}$, and delivered N, P, and $\mathrm{K}$ at 50,11 , and $42 \mathrm{~kg} \cdot \mathrm{ha}^{-1}$, respectively. On the final fertigation, $\mathrm{Mg}$ was supplied (as $\left.\mathrm{MgSO}_{4} \cdot 7 \mathrm{H}_{2} \mathrm{O}\right)$ to all treatments at $50 \mathrm{mg} \cdot \mathrm{L}^{-1}$ (equivalent to $20 \mathrm{~kg} \mathrm{Mg} / \mathrm{ha}$ ), to overcome an apparent $\mathrm{Mg}$ deficiency (interveinal chlorosis of basal shoot leaves) induced by the 7.5 and $15.0 \mathrm{t} \cdot \mathrm{ha}^{-1}$ gypsum treatments and noted at the end of the 1995 growing season. The EC of each fertigation solution averaged $1.5 \mathrm{dS} \cdot \mathrm{m}^{-1}$ and $\mathrm{pH}$ ranged from 6.4 to 6.7 .

Field sampling, data collection, and analysis. Soil samples were collected on $2 \mathrm{Apr}$. 1995 (1 d before gypsum application), 28 Apr. 1996 (following the first growing season), and 16 Oct. 1996 (following the second growing season). Two soil cores measuring $20 \mathrm{~cm}$ in depth and $2.5 \mathrm{~cm}$ in diameter were taken from the midpoints of the outer and middle trees of each replication. Soils were dried at $60{ }^{\circ} \mathrm{C}$ for 2 weeks and passed through a $1-\mathrm{mm}$ sieve. A 100-g subsample was used to prepare the soil saturation extract (U.S. Salinity Laboratory Staff, 1954), and the $\mathrm{pH}$ and EC were determined, followed by the concentrations of $\mathrm{Na}, \mathrm{Ca}$, and $\mathrm{Mg}$ using an inductively-coupled plasma emission (ICP) spectrometer (JY70+, Instruments S.A., Edison, N.J.). Total Kjeldahal $\mathrm{N}$ (TKN) concentration was determined using an autoanaylzer (model II, Technicon Instru- ments Corp., Tarrytown, N.Y.) following the SoilConservation Service extraction procedure (1972). Phosphorus was extracted with 0.5 M $\mathrm{NaHCO}_{3}$ (Olsen and Sommers, 1982), K in 1 soil : 5 water (by volume) extracts, and their concentrations determined by ICP spectrometry. Concentrations of $\mathrm{N}, \mathrm{P}$, and $\mathrm{K}$ were expressed as $\mathrm{mg} \cdot \mathrm{kg}^{-1}$ dried soil.

Starting on the day of planting and throughout the 1995 and 1996 growing seasons, we monitored increases in tree height (at the terminal bud of the central leader), total lateral branch extension, trunk cross-sectional area (TCSA), and net dry matter accumulation and net macroelement uptake by roots and combined trunk plus lateral branches. There was high tree-to-tree variability in the timing of complete leaf abscission, which was unrelated to previous gypsum application rate. By late October, for example, about one-third of the trees had completely defoliated, with the remainder in various stages of defoliation. In our conditions, it was not possible to collect all leaves from all treatments and replicates in a timely manner; thus, no leaf biomass data are presented.

The increase in tree height at the terminal bud of the central leader was determined between the dates of 7 Apr. 1995 and 17 Oct. 1996 after subtracting the initial height at planting. Total lateral branch extension was measured on 17 Oct. 1996 by summing the lengths of all lateral branches on the tree. No lateral branches were present on the day of planting. A caliper was used to measure trunk diameter $2.5 \mathrm{~cm}$ above the ground line on 7 Apr. and 29 Sept. 1995, and on 17 Oct. 1996; the increases in TCSA were then determined between the first to second, and second to third time intervals, which approximated the period of trunk growth during the 1995 and 1996 growing seasons, respectively. Visual ratings for general health and vigor were recorded on 29 Sept. 1995 and 17 Oct. 1996, with a scale of 1 (greatest health and vigor) to 5 (least health and vigor). Tree survival was also recorded on 17 Oct. 1996.

At the end of the second growing season (17 Oct. 1996), the trees were excavated and fractionated into roots and combined trunk plus lateral branches. Soil was washed from the roots with tap water; then roots and the combined trunk plus lateral branches were rinsed with deionized water. The tissues were dried at 60 ${ }^{\circ} \mathrm{C}$ for 2 weeks, weighed, and ground to pass a 40-mesh $(0.635-\mathrm{mm})$ screen. Dry matter accumulation in roots and combined trunk plus lateral branches was determined for the duration of gypsum treatment (7 Apr. 1995 to 17 Oct. 1996) after subtracting the average dry weight per organ obtained at planting. Ground tissues were subjected to acid block digestion (Parkinson and Allen, 1975). The concentrations of $\mathrm{P}, \mathrm{K}, \mathrm{Ca}, \mathrm{Mg}$, and $\mathrm{S}$ were determined by ICP spectrometry, and TKN by autoanalyzer.

Data were analyzed with analysis of variance as a randomized complete-block design with six replications (blocks). For soil data, each replication was a single analytical determination derived from two pooled soil cores. For 
increases in tree height, lateral branch length, TCSA, biomass, and macroelement content, and for the tree visual rating, the average value of three trees comprised a replication. The ground tissues from the three trees per replication were pooled for mineral analysis; thus, mineral-related data are the means of six analytical determinations per treatment. Macroelement content per organ at the time of tree excavation (17 Oct. 1996) was determined as the product of the three-tree average organ dry weight and the three-tree average macroelement concentration of the excavated trees. Average macroelement content per organ at planting was also determined (as above), and then subtracted from the value obtained at excavation to determine net macroelement uptake per tree during the time of gypsum treatment, discounting the net uptake by leaves. Where significant, sums of squares for gypsum application main effects were partitioned into single degree of freedom linear and quadratic orthogonal contrasts.

\section{Results}

Soil compositional changes. One day before gypsum application, soil saturation extract $\mathrm{pH}$, $\mathrm{EC}$, and cationic characteristics did not differ between the marked treatment experimental units (2 Apr. 1995 sampling date in Table 1). At this time, TKN concentration ranged between 550 and $589 \mathrm{mg} \cdot \mathrm{kg}^{-1}$ dry weight, $\mathrm{P}$ between 39 and $40 \mathrm{mg} \cdot \mathrm{kg}^{-1}$ dry weight, and $\mathrm{K}$ between 20 and $26 \mathrm{mg} \cdot \mathrm{kg}^{-1}$ dry weight, with no differences between the treatment plots (data not shown). Thereafter, soil saturation extract $\mathrm{pH}$, and the concentrations of TKN, P, and $\mathrm{K}$ were unaffected by gypsum rate throughout the study period (data not shown).

The soil saturation extract EC (ECe) of the control treatment (gypsum at $0.0 \mathrm{t} \cdot \mathrm{ha}^{-1}$ ) was identical at each sampling date, but at the second sampling date (13 months after gypsum application), $\mathrm{EC}_{\mathrm{e}}$ had increased by 1.8 to 3.4 times because of gypsum application (Table 1 ). By the end of the study (18 months after gypsum application), only the highest gypsum rate increased $\mathrm{EC}_{\mathrm{e}}$. In the control treatment, $\mathrm{Mg}$ and $\mathrm{Ca}$ concentrations in the soil saturation extract declined throughout the study period. In contrast, soil saturation extract $\mathrm{Mg}$ and $\mathrm{Ca}$ concentrations of the 7.5 and $15.0 \mathrm{t} \cdot \mathrm{ha}^{-1}$ gypsum treatments increased at the second sampling date, then declined at the third sampling date. Both $\mathrm{Mg}$ and $\mathrm{Ca}$ concentrations in the soil saturation extract were increased by increasing gypsum rate by the second sampling date, but only the Ca concentration remained high after gypsum application by the third sampling date.

Repeated irrigation with $\mathrm{Na}$-affected water increased the soil saturation extract Na concentration (Table 1; across-treatment averages of $1.4 \mathrm{meq} \cdot \mathrm{L}^{-1}$ before irrigation to $4.0 \mathrm{meq} \cdot \mathrm{L}^{-1}$ at the second and third samplings). However, gypsum rate did not affect $\mathrm{Na}$ concentration in the soil saturation extract. Therefore, the significant inverse relationship (linear contrast) between gypsum rate and soil saturation extract SAR after the addition of the
Na-affected irrigation water (Table 1; second and third samplings) was mainly the result of the increase in soil saturation extract $\mathrm{Ca}$ concentration contributed by gypsum. While the increases in Ca persisted, their magnitude waned by the end of the study.

Tree survival, growth, and appearance. Eighteen months following gypsum application and transplanting, an average of $89 \%$ to $95 \%$ of trees on gypsum-treated soil had survived, while only $78 \%$ of the control trees had survived. Because of mortality, rather than having six, three-tree replications, the final tree analyses included two single-tree replications for the control treatment, two double-tree replications for gypsum at 7.5 $\mathrm{t} \cdot \mathrm{ha}^{-1}$, and one double-tree replication for gypsum at $15.0 \mathrm{t} \cdot \mathrm{ha}^{-1}$. Only surviving trees were included in the foregoing analyses. The remaining replications were comprised of three trees, maintaining the original total of six replications per treatment.

There was a positive relationship between gypsum application and the increase in tree height 18 months after transplanting (Table 2). However, this trend was not statistically significant. Gypsum rate also did not affect

Table 1. Soil saturation extract $\mathrm{pH}$, electrical conductivity (EC), selected cations, and sodium adsorption ratio (SAR) to a depth of $20 \mathrm{~cm}$ before and during 18 months of gypsum treatment and field establishment of A. triloba trees. $^{z}$

\begin{tabular}{|c|c|c|c|c|c|c|c|}
\hline \multirow{3}{*}{$\begin{array}{l}\text { Sampling } \\
\text { date }^{y}\end{array}$} & \multirow{3}{*}{$\begin{array}{l}\text { Gypsum } \\
\text { rate }\left(\mathrm{t} \cdot \mathrm{ha}^{-1}\right)\end{array}$} & \multicolumn{6}{|c|}{ Soil saturation extract characteristic } \\
\hline & & \multirow[b]{2}{*}{$\mathrm{pH}$} & \multirow[b]{2}{*}{$\mathrm{EC}\left(\mathrm{dS} \cdot \mathrm{m}^{-1}\right)$} & \multicolumn{3}{|c|}{$\mathrm{meq} \cdot \mathrm{L}^{-1}$} & \multirow[b]{2}{*}{ SAR $^{x}$} \\
\hline & & & & $\mathrm{Mg}$ & $\mathrm{Ca}$ & $\mathrm{Na}$ & \\
\hline \multirow[t]{3}{*}{2 Apr. 1995} & 0.0 & 5.24 & 0.55 & 0.77 & 2.61 & 1.48 & 1.15 \\
\hline & 7.5 & 5.15 & 0.52 & 0.71 & 2.47 & 1.24 & 0.98 \\
\hline & 15.0 & 5.08 & 0.48 & 0.60 & 2.21 & 1.58 & 1.33 \\
\hline Significance & & NS & NS & NS & NS & NS & NS \\
\hline \multirow[t]{3}{*}{28 Apr. 1996} & 0.0 & 5.08 & 0.55 & 0.25 & 1.38 & 3.64 & 4.49 \\
\hline & 7.5 & 5.26 & 0.97 & 0.95 & 5.29 & 4.54 & 3.88 \\
\hline & 15.0 & 5.21 & 1.87 & 2.48 & 17.61 & 3.74 & 1.31 \\
\hline Significance & & NS & ** & * & ** & NS & * \\
\hline $\mathrm{L}$ & & --- & ** & ** & ** & --- & * \\
\hline Q & & --- & NS & NS & NS & --- & NS \\
\hline \multirow[t]{3}{*}{16 Oct. 1996} & 0.0 & 5.31 & 0.55 & 0.07 & 0.87 & 5.05 & 8.75 \\
\hline & 7.5 & 5.41 & 0.55 & 0.11 & 1.80 & 3.97 & 4.81 \\
\hline & 15.0 & 5.34 & 0.90 & 0.82 & 7.06 & 3.06 & 2.46 \\
\hline Significance & & NS & * & NS & * & NS & $*$ \\
\hline $\mathrm{L}$ & & --- & * & --- & $* *$ & --- & $* *$ \\
\hline Q & & --- & NS & --- & NS & --- & NS \\
\hline
\end{tabular}

${ }^{2}$ Each value is the mean of six replications.

${ }^{y}$ Gypsum was applied on 3 Apr. 1995, trees were planted on 7 Apr. 1995, and excavated for analysis on 17 Oct. 1996.

${ }^{\mathrm{x}}$ Calculated as $\mathrm{Na} /[(\mathrm{Ca}+\mathrm{Mg}) / 2]^{1 / 2}$, all ions in meq. $\cdot \mathrm{L}^{-1}$.

Ns, *** Nonsignificant or significant at $P \leq 0.05$ or 0.01 , respectively; linear $(\mathrm{L})$ or quadratic $(\mathrm{Q})$ orthogonal contrasts partitioned from the sums of squares for main effect of gypsum rate.

Table 2. The effects of gypsum application on 3 Apr. 1995 on increases in A. triloba tree height, total lateral branch extension, and trunk cross-sectional area (TCSA), from 7 Apr. 1995 to 17 Oct. 1996. Trees were visually rated in Fall 1995 and $1996 .^{2}$

\begin{tabular}{|c|c|c|c|c|c|}
\hline \multirow{2}{*}{$\begin{array}{l}\text { Gypsum } \\
\text { rate }\left(\mathrm{t} \cdot \mathrm{ha}^{-1}\right)\end{array}$} & \multirow{2}{*}{$\begin{array}{l}\text { Increase in } \\
\text { tree ht }(\mathrm{cm})\end{array}$} & \multirow{2}{*}{$\begin{array}{l}\text { Lateral branch } \\
\text { extension }(\mathrm{cm})\end{array}$} & \multirow{2}{*}{$\begin{array}{c}\text { Increase in } \\
\text { TCSA }\left(\mathrm{mm}^{2}\right)\end{array}$} & \multicolumn{2}{|c|}{ Visual tree rating $^{y}$} \\
\hline & & & & 1995 & 1996 \\
\hline$\overline{0.0}$ & 38.7 & 63.8 & 99.0 & 3.8 & 3.8 \\
\hline 7.5 & 49.3 & 102.2 & 185.2 & 2.8 & 3.2 \\
\hline 15.0 & 49.8 & 110.4 & 166.5 & 2.5 & 2.9 \\
\hline Significance & NS & $*$ & * & $*$ & * \\
\hline $\mathrm{L}$ & --- & ** & * & ** & * \\
\hline Q & --- & NS & NS & NS & NS \\
\hline
\end{tabular}

${ }^{2}$ Each value is the mean of six replications.

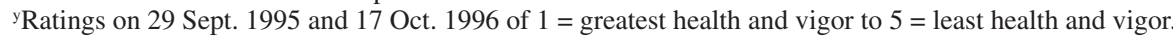
Ns, ,***Nonsignificant or significant at $P \leq 0.05$ or 0.01 , respectively; linear (L) or quadratic (Q) orthogonal contrasts partitioned from the sums of squares for main effect of gypsum rate. 
Depending on gypsum rate, total dry weight per tree at the time of tree excavation had increased by 15 - to 33 -fold above the average value at transplanting. Final dry weights were variable within treatments. The average $\mathrm{CV}$ values across the gypsum rates for dry weight of roots, trunk plus lateral branches, and their combined totals were $30.9 \%, 44.4 \%$, and $32.6 \%$, respectively. Trunk plus lateral branches comprised a relatively small fraction of the total excavated tree dry weight (23\% across the treatments).

During the 18 months after gypsum application, over twice the amount of dry matter had accumulated in tops and roots of trees growing on gypsum-amended soil as compared to trees on the non-amended soil (Fig. 1A). Total dry matter gain per tree was 79 to $84 \mathrm{~g}$ higher under the gypsum-amended conditions in relation to controls. From $71 \%$ to $78 \%$ of the difference in total tree dry matter gain between trees on gypsum-amended soil and those not on gypsum-amended soil was attributed to the difference in root dry matter accumulation. Linear contrasts for dry matter accumulation in trunk plus lateral branches, roots, and their combined totals were significant at $P \leq 0.05$, even though there was little variation in organ dry matter gains between the 7.5 and $15.0 \mathrm{t} \cdot \mathrm{ha}^{-1}$ gypsum treatments.

Macroelement concentrations and net uptake per tree. At the time of tree excavation, none of the macroelement concentrations $(\mathrm{N}$, $\mathrm{P}, \mathrm{K}, \mathrm{Ca}, \mathrm{Mg}$, and $\mathrm{S}$ expressed as percentage of dry weight) in roots and combined trunk plus lateral branches were affected by gypsum rate (Table 3). The average Cv (across the treatments) ranged from $7 \%$ to $18 \%$.

Because of the gypsum rate effects on tree biomass accumulation but similarity in mineral concentrations between the gypsum rates, the net uptake of $\mathrm{N}, \mathrm{P}$, and $\mathrm{K}$ by roots and combined trunks plus lateral branches followed the same trend with gypsum rate as did the accumulation of dry matter in these tissues (Fig. 1B-D). Identical patterns were observed for net $\mathrm{Ca}, \mathrm{Mg}$, and $\mathrm{S}$ uptake (data not shown). High variability in total net $\mathrm{N}, \mathrm{P}$, and $\mathrm{K}$ uptake per tree within the gypsum rates (CV average of $32 \%$ to $39 \%$, depending on the element) resulted primarily from the relatively high variability in biomass accumulation, and to a lesser degree from variability in macroelement concentrations within gypsum rates, as noted above.

Following transplanting, the net uptake of $\mathrm{N}$, P, and $\mathrm{K}$ per tree (trunk, lateral branches, and roots) was equivalent to levels that were 10- to 21-fold (N), 11- to 24-fold (P), and 7- to 15 -fold $(\mathrm{K})$ those measured in the trees at the time of transplanting. Gypsum rate did not significantly affect the net uptake of N, P, and $\mathrm{K}$ by trunks plus lateral branches (Fig. 1B-D), nor did it affect total net macroelement uptake (roots + trunks + lateral branches) when expressed as a function of the unit increase in root dry weight between transplanting to excavation (data not presented). However, total net $\mathrm{N}, \mathrm{P}$, and $\mathrm{K}$ uptake per tree increased with gypsum rate, because of the large influence of gypsum on the accumulation of biomass
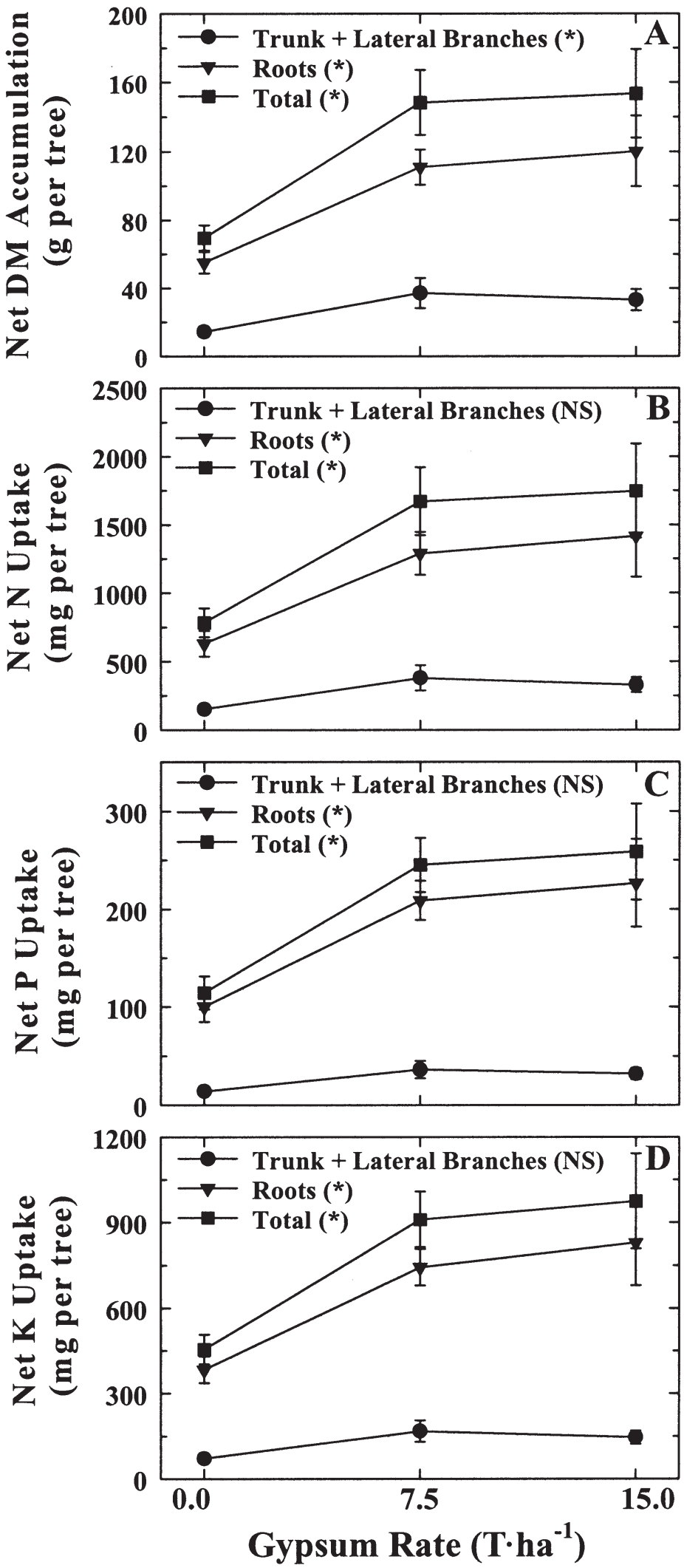

Fig. 1. Influence of gypsum rate on net dry matter (DM) accumulation (A) and the net uptake of $\mathrm{N}, \mathrm{P}$, and $\mathrm{K}(\mathbf{B}, \mathbf{C}$, and $\mathbf{D}$, respectively) by trunks, lateral branches, and roots during 18 months of field establishment of A. triloba. Significance (*) or nonsignificance (NS) of linear orthogonal contrast partitioned from the main effects of gypsum rate $(P \leq 0.05)$. Each value is the mean $+\mathrm{SE}$ of six replications. Initial values at transplanting: root dry weight ( $3.7 \mathrm{~g}$ per tree); trunk plus lateral branch dry weight ( $0.9 \mathrm{~g}$ per tree); root $\mathrm{N}, \mathrm{P}$, and $\mathrm{K}$ content (66.0, 9.3, and 59.7 $\mathrm{mg}$ per tree, respectively); trunk plus lateral branch $\mathrm{N}, \mathrm{P}$, and $\mathrm{K}$ content (15.7, 1.5 , and $5.6 \mathrm{mg}$ per tree, respectively). 
Table 3. Macroelement concentrations in roots and combined trunks plus lateral branches, expressed as percentage of dry weight, of excavated A. triloba trees (17 Oct. 1996). ${ }^{2}$

\begin{tabular}{|c|c|c|c|c|c|c|c|c|c|c|c|c|}
\hline \multirow{2}{*}{$\begin{array}{l}\text { Gypsum } \\
\text { rate }\left(\mathrm{t} \cdot \mathrm{ha}^{-1}\right)\end{array}$} & \multicolumn{6}{|c|}{ Roots } & \multicolumn{6}{|c|}{ Trunks plus lateral branches } \\
\hline & $\mathrm{N}$ & $\mathrm{P}$ & $\mathrm{K}$ & $\mathrm{Ca}$ & $\mathrm{Mg}$ & $\mathrm{S}$ & $\mathrm{N}$ & $\mathrm{P}$ & $\mathrm{K}$ & $\mathrm{Ca}$ & $\mathrm{Mg}$ & $\mathrm{S}$ \\
\hline 0.0 & 1.17 & 0.18 & 0.75 & 0.36 & 0.13 & 0.19 & 1.09 & 0.10 & 0.50 & 0.42 & 0.11 & 0.07 \\
\hline 7.5 & 1.17 & 0.19 & 0.71 & 0.39 & 0.13 & 0.21 & 1.04 & 0.10 & 0.46 & 0.42 & 0.10 & 0.07 \\
\hline 15.0 & 1.18 & 0.19 & 0.72 & 0.37 & 0.12 & 0.20 & 1.04 & 0.10 & 0.46 & 0.41 & 0.10 & 0.07 \\
\hline Significance & NS & NS & NS & NS & NS & NS & NS & NS & NS & NS & NS & NS \\
\hline
\end{tabular}

${ }^{\mathrm{z}}$ Each value is the mean of six replications.

${ }^{n s}$ Nonsignificant for main effect of gypsum rate at $P \leq 0.05$.

(and thus the macroelements) in roots. Under gypsum-amended conditions, 660 to 785 $\mathrm{mg}$ more $\mathrm{N}$ per tree, 109 to $126 \mathrm{mg}$ more $\mathrm{P}$ per tree, and 360 to $446 \mathrm{mg}$ more $\mathrm{K}$ per tree had accumulated in roots as compared to the control treatment.

\section{Discussion}

The SAR of the irrigation water used in the present study exceeds a level that is known to induce clay particle dispersion and adversely affect internal drainage (Miyamoto et al., 1995). In the non-gypsum (control) treatment, the continuous increases in soil saturation extract $\mathrm{Na}: \mathrm{Ca}$ equivalent ratio and SAR (Table 1) were a reflection of repeated irrigation with the Na-affected water. Gypsum application limited the extent of soil sodicity by increasing the soil saturation extract $\mathrm{Ca}$ concentration by as much as 13 times, depending on gypsum rate and time following the application. This long-established effect of gypsum is known to increase stability (e.g., flocculation) of clay mineral aggregates and thereby improve soil permeability, aeration, and internal drainage in Na-affected soils (Bohn et al., 1985).

During the course of the final growing season, there was a sharp reduction in soil saturation extract $\mathrm{Ca}$ concentration with a marginal increase in soil saturation extract SAR with the highest gypsum rate $\left(15.0 \mathrm{t} \cdot \mathrm{ha}^{-1}\right)$. This indicates that repeated gypsum applications may be necessary beyond the conditions of this study to maintain a favorable soil condition for A. triloba orchard management with $\mathrm{Na}$-affected irrigation water. The apparent $\mathrm{Mg}$ deficiency observed after the first growing season (gypsum-treated trees only) may have resulted from $\mathrm{Ca}$ antagonism of $\mathrm{Mg}$ uptake (Mengel and Kirkby, 1987). Accordingly, in irrigated conditions combined with gypsum application on soils of low-Mg availability (as in our study), $\mathrm{Mg}$ fertilization may be essential for this species. Coincidentally, the higher soil saturation extract $\mathrm{Mg}$ concentrations of the gypsum-amended soil at the second sampling date had a negligible effect on soil saturation extract SAR, and may have resulted from impurities in the agricultural grade gypsum.

Asimina triloba is reported to possess a dominant taproot that may be adaptive for exploring the soil profile in its indigenous riparian habitats (Nash and Graves, 1993). The degree to which soil can be penetrated by roots is dependent on the soil-related physical functions of $\mathrm{Ca}$ listed above (Mengel and Kirkby, 1987; Simpson et al., 1997), and in the present study, variation in A. triloba root growth comprised over $70 \%$ of the difference in tree biomass accumulation between trees on amended and non-amended soil. Root growth is also directly dependent on $\mathrm{Ca}$ in the soil solution (Hanson, 1984; Picchioni et al., 2001; Poovaiah and Reddy, 1991). While the Ca requirement of $A$. triloba is not adequately known, the saturation extract $C a$ concentration at $15.0 \mathrm{t} \cdot \mathrm{ha}^{-1}$ gypsum was in the range of a calcareous soil (Picchioni et al., 1990). We did not determine the extent of Ca transport or root penetration into the dominant red clay subsoil, where gypsum would be expected to exert a significant influence on the physical properties of Na-affected soil. Further study is needed to evaluate variation in A. triloba root growth restriction in Na-affected, high-clay soils of varying $\mathrm{Ca}$ status.

Numerous $A$. triloba cultivars have originated from Ohio and Indiana (Callaway, 1990), and high concentrations of A. triloba occur at the southern borders of these states along the Ohio River (Jacquart et al., 1992; Journal of Heredity, 1917; Zimmerman, 1941). It is therefore noteworthy that alluvial soils of the Ohio River floodplain and its associated terraces bordering the states of Ohio and Indiana are dominated by limestone parent material, underlain by limestone, or underlain by calcareous gravel(e.g., the Huntington-Wheeling and Genesee-Huntsville-Wabash stream bottomland soil associations described by Aandahl et al., 1960). Asimina parviflora (Michx.) Dunal, a related species, is reported to inhabit "lime sinks" within much of the southern U.S. indigenous range of A. triloba (Callaway and Callaway, 1992). Still later observation has revealed the presence of $A$. triloba as a dominant understory species on a calcareous upland site in central Illinois (Ebinger et al., 1997), and that Ca may be a limiting factor for A. triloba seedling growth in a root-confined (containerized) greenhouse environment (Pomper et al., 2002b). Taken together, these findings support the possibility that improved establishment of A. triloba in the gypsum-amended conditions was, at least in part, related to $\mathrm{Ca}$ function in root growth and development.

For trees on gypsum-amended soil, total dry matter accumulation and the net uptake of $\mathrm{N}, \mathrm{P}$, and $\mathrm{K}$ per tree were at least twice the amount of their nontreated counterparts at the same level of total soil $\mathrm{N}$ fertility (expressed as TKN concentration). The relatively poor edaphic establishment environment created by the low-Ca, high-Na conditions may increase residual $\mathrm{NO}_{3}$ concentration in the soil, which in turn would be subject to various loss mechanisms, particularly leaching. Greater macroelement uptake per tree (Ca-amended conditions) is of practical interest for fertilizer nutrient recovery in orchards (Weinbaum et al., 1992), and for maximizing the environmental benefits of Na-affected agroforestry uses of A. triloba (Robles-Diaz-de-León and NavaTudela, 1998).

In summary, gypsum supplementation may represent a useful addition to $A$. triloba orchard management under relatively low saline but high-Na conditions, particularly for increasing growth of trunk and roots during establishment, and for increasing fertilizer nutrient recovery. Intraspecific variation in plant response to $\mathrm{Ca}$ has been documented (Snaydon, 1962; Snaydon and Bradshaw, 1961). Ecotypic variation in genetic composition among marginal populations of A. triloba (e.g., those on the geographic extremities of the species distribution) has also been reported (Huang et al., 1998). Further research is needed to determine whether edaphic differentiation exists among $A$. triloba populations with respect to their responses to $\mathrm{Ca}$. In addition, more detailed study at the soil : root level could elucidate whether the beneficial effects of gypsum on A. triloba in the Na-affected conditions resulted from improvement of soil physical properties, directly from $\mathrm{Ca}$ as nutritional factor, or a combination of both. Such study, for example, could determine the relative importance of $\mathrm{Ca}$ fertilization for low$\mathrm{Na}$ A. triloba field plantings.

\section{Literature Cited}

Aandahl, A.R., J.K. Ableiter, O.W. Bidwell, J.Elder, F.D. Hole, N. Holowaychuk, H.H. Krusekopf, J.E. McClelland, P.R. McMiller, H.F. Arneman, R.T. Odell, F.F. Riecken, H.P. Ulrich, T.M. Bushnell, F.C. Westin, E.P. Whiteside, I.F. Schneider, G.M. Browning, and R.J. Muckenhirn. 1960. Associations of soil series in the north central region, p. 70-118. In: J.K. Ableiter, R.T. Odell, F.C. Westin, and E.P. Whiteside (eds.). Soils of the north central region of the United States. Univ. of Wisconsin (Madison) Agr. Expt. Sta. Bul. 544.

Bohn, H., B. McNeal, and G. O'Connor. 1985. Soil chemistry. Wiley, New York.

California Fertilizer Association. 1995. Western fertilizer handbook. 8th ed. Calif. Fert. Assn. Soil Improvement Comm. Interstate Publ., Danville, Ill.

Callaway, M.B. 1990. The pawpaw (Asimina triloba). Kentucky State Univ. Publ. CRS-Hort1-901T.

Callaway, M.B. 1992. Current research for the commercial development of pawpaw [Asimina triloba (L.) Dunal]. HortScience 27:90, 191.

Callaway, M.B. and D.J. Callaway 1992. Our native pawpaw: The next new commercial fruit? Arnoldia 52(3):20-29.

Darrow, G.M. 1975. Minor temperate fruits, p. 269-284. In: J. Janick and J.N. Moore (eds.). Advances in fruit breeding. Purdue Univ. Press, West Lafayette, Ind.

Ebinger, J., D. O'Connel, S. Turner, F. Catchpole, and W. McClain. 1997. Vegetation survey of Elkhard Woods, Logan County, Illinois. Castanea 62:74-81.

Epstein, E. 1961. The essential role of calcium in selective cation transport by plant cells. Plant Physiol. 36:437-444.

Hanson, J.B. 1984. The functions of calcium in plant nutrition, p. 149-208. In: P.B. Tinker and A. Läuchli (eds.). Advances in plant nutrition. vol. I. Praeger, New York.

Huang, H., D.R. Layne, and D.E. Riemenschneider. 1998. Genetic diversity and geographic dif- 
ferentiation in pawpaw [Asimina triloba $(\mathrm{L}$.) Dunal] populations from nine states as revealed by allozyme analysis. J. Amer. Soc. Hort. Sci. 123:635-641.

Huang, H., D.R. Layne, and T.L. Kubisiak. 2003. Molecular characterization of cultivated pawpaw (Asimina triloba) using RAPD markers. J. Amer. Soc. Hort. Sci. 128:85-93.

Jacquart, E.M., T.V. Armentano, and A.L. Spingarn. 1992. Spatial and temporal tree responses to water stress in an old-growth deciduous forest. Amer. Mid. Nat. 127:158-171.

Journal of Heredity. 1917. The best pawpaws. J. Hered. 8:21-33.

Karakas, B., R.L. Bianco, and M. Rieger. 2000. Association of marginal leaf scorch with sodium accumulation in salt-stressed peach. HortScience 35:83-84.

Layne, D.R. 1996. The pawpaw [Asimina triloba (L.) Dunal]: A new fruit crop for Kentucky and the United States. HortScience 31:777-784.

Mengel, K. and E.A. Kirkby. 1987. Principles of plant nutrition. Intl. Potash Inst., WorblaufenBern, Switzerland.

Miyamoto, S., L.B. Fenn, and D. Swietlik. 1995. Flow, salts, and trace elements in the Rio Grande: A review. Texas Water Resources Inst. Publ. TR-169. TWRI, Texas Agr. Expt. Sta., College Station.

Nash, L.J. and W.R. Graves. 1993. Drought and flood stress effects on plant development and leaf water relations of five taxa of trees native to bottomland habitats. J. Amer. Soc. Hort. Sci. 118:845-850.

Nelson, D.W. and L.E. Sommers. 1996. Total carbon, organic carbon, and organic matter, p. 961-1010. In: D.L. Sparks et al. (eds.). Methods of soil analysis. Part 3. Chemical methods. SSSA Book Ser. No. 5, Madison, Wis.

Olsen, S.R. and L.E. Sommers. 1982. Phosphorus, p. 403-430. In: A.L. Page (ed.). Methods of soil analysis. Part 2. Chemical and microbiological properties. Agron. Monogr. No. 9 (2nd ed.). ASA-SSSA, Madison, Wis.

Parkinson, J.A. and S.E. Allen. 1975. A wet oxidation technique suitable for the determination of nitrogen and mineral nutrients in biological materials. Commun. Soil. Sci. Plant. Anal. 6:1-11.

Picchioni, G.A. and C.J. Graham. 2001. Salinity, growth, and ion uptake selectivity of con- tainer-grown Crataegus opaca. Scientia Hort. 90:151-166

Picchioni, G.A., H. Karaca, L. Boyse, B.D. McCaslin, and E.A. Herrera. 2000. Salinity, boron, and irrigated pecan productivity along New Mexico's Rio Grande Basin. J. Environ. Qual. 29:955-963.

Picchioni, G.A, S. Miyamoto, and J.B. Storey. 1990. Salt effects on growth and ion uptake of pistachio rootstocks. J. Amer. Soc. Hort. Sci. 115:647-653.

Picchioni, G.A., S. Miyamoto, and J.B. Storey. 1991. Rapid testing of salinity effects on pistachio rootstock seedlings. J. Amer. Soc. Hort. Sci. 116:555-559.

Picchioni, G.A., M. Valenzuela-Vazquez, and S. Armenta-Sanchez. 2001. Calcium-activated root growth and mineral nutrient accumulation of Lupinus havardii Wats.: Ecophysiological and horticultural significance. J. Amer. Soc. Hort. Sci. 126:631-637.

Pomper, K.W., D.R. Layne, and S.C. Jones. 2002a. Incident irradiance and cupric hydroxide container treatment effects on early growth and development of container-grown pawpaw seedlings. J. Amer. Soc. Hort. Sci. 127:13-19.

Pomper, K.W., D.R. Layne, S.C. Jones, and M.G. Kwantes. 2002b. Growth enhancement of container-grown pawpaw seedlings as influenced by media type, root-zone temperature, and fertilization regime. HortScience 37:329-333.

Pomper, K.W.,D.R.Layne, andE.B. Reed.2002c.Determination of the optimal rate of slow-release fertilizer for enhanced growth of pawpaw seedlings in containers. HortTechnology 12:397-402.

Poovaiah, B.W. and S.N. Reddy. 1991. Calcium and root development, p. 205-227. In:Y.Waisel and A. Eshel (eds.). Plant roots: The hidden half. Marcel Dekker, New York.

Robles-Diaz-De-León, L.F. and A. Nava-Tudela. 1998. Playing with Asimina triloba (pawpaw): A species to consider when enhancing riparian forest buffer systems with non-timber products. Ecol. Modeling 112:169-193.

Simpson, J.R.,A. Pinkerton, and J. Lazdovskis. 1997. Effects of subsoil calcium on the root growth of some Lucerne genotypes (Medicago sativa L.) in acidic soil profiles. Austral. J. Agr. Res. 28:629-638.

Snaydon, R.W. 1962. The growth and competitive ability of contrasting natural populations of Trifolium repens $\mathrm{L}$. on calcareous and acid soils. J. Ecol. 50:439-447.

Snaydon, R.W. andA.D. Bradshaw. 1961. Differential response to calcium within the species Festuca ovina L. New Phytol. 60:219-235.

Soil Conservation Service. 1972. Soil survey laboratory methods and procedures for collecting soil samples. U.S. Dept.. Agr., Wash., D.C.

Thimijan, R.W. and R.D. Heins. 1983. Photometric, radiometric, and quantum light units of measure: A review of procedures for interconversion. HortScience 18:818-822.

U.S. Geological Survey. 1991. Water resources data-Louisiana-Water year 1991. U.S. Geological Survey Water Data Rpt. LA-91-1. U.S. Dept. Interior, Wash., D.C.

U.S. Salinity Laboratory Staff. 1954. Diagnosis and improvement of saline and alkali soils. U.S. Dept. Agr. Hdbk. 60.

Wallis, E.S., I.M. Wood, and D.E. Byth. 1989. New crops: A suggested framework for their selection, evaluation, and commercial development, p. 36-52. In: G.E. Wickens, N. Haq, and P. Day (eds.). New crops for food and industry. Chapman and Hall, New York.

Weinbaum, S.A., R.S. Johnson, and T.M. DeJong. 1992. Causes and consequences of overfertilization in orchards. HortTechnology 2:112-121.

Worthington, J.W., J. Lasswell, and M.J. McFarland. 1986. Trickle irrigation in the '80s. Pecan South 20(1):4-6.

Wright, G.C., K.D. Patten, and M.C. Drew. 1992. Salinity and supplemental calcium influence growth of rabbiteye and southern highbush blueberry. J. Amer. Soc. Hort. Sci. 117:749-756.

Zekri, M. and L. Parsons. 1990. Calcium influences growth and leaf mineral concentration of citrus under saline conditions. HortScience 25:784-786.

Zhao, G.X., M.J. Rieser, Y.H. Hui, L.R. Miesbauer, D.L. Smith, and J.L. McLaughlin. 1993. Biologically active acetogenins from stem bark of Asimina triloba. Phytochemistry 33:1065-1073.

Zimmerman, G.A. 1941. Hybrids of the American pawpaw. J. Hered. 32:83-91.

Ziska, L.H., T.M. DeJong, G.F. Hoffman, and R.M. Mead. 1991. Sodium and chloride distribution in salt-stressed Prunus salicina, a deciduous tree species. Tree Physiol. 8:47-57. 